Volume 2

Number 12014 Student Articles Edition

Article 6

2014

\title{
Spanish and Mexican Land Grants and Heirs' Rights to Unclaimed Mineral Estates in Texas
}

Rose Richerson

Texas A\&M University School of Law

Follow this and additional works at: https://scholarship.law.tamu.edu/journal-of-property-law

Part of the Law Commons

\section{Recommended Citation}

Rose Richerson, Spanish and Mexican Land Grants and Heirs' Rights to Unclaimed Mineral Estates in Texas, 2 Tex. A\&M J. Real Prop. L. 97 (2014).

Available at: https://doi.org/10.37419/JPL.V2.11.5

This Student Article is brought to you for free and open access by Texas A\&M Law Scholarship. It has been accepted for inclusion in Texas A\&M Journal of Property Law by an authorized editor of Texas A\&M Law Scholarship. For more information, please contact aretteen@law.tamu.edu. 


\title{
SPANISH AND MEXICAN LAND GRANTS AND HEIRS' RIGHTS TO UNCLAIMED MINERAL ESTATES IN TEXAS
}

\author{
By Rose Richerson†
}

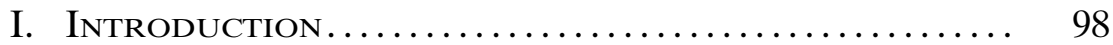

II. The History of Spanish and Mexican Land

Grants in Texas ............................. 101

A. The History of Texas Lands .................. 101

1. Spanish and Mexican Sovereignty ............ 101

2. The Republic of Texas .................... 102

3. The State of Texas ...................... 103

4. The Treaty of Guadalupe-Hidalgo ........... 103

5. Historical Land Grant Commissions ........... 104

B. Mineral Estates in the State of Texas ............. 106

C. Historical Social, Political, and Cultural Issues ...... 107

III. Texas Land Grant Dispute Case History ........ 108

A. General Land Claims ......................... 108

B. Mineral Estate Claims ........................ 113

IV. Current Obstacles and Rights for Heirs ......... 114

A. Current Texas Property Law ................... 114

1. Mineral Estate Rights in Texas ............. 115

B. Heirs and Land Grant Claims Today ............. 118

V. The Future for Heirs and Land Grant Claims... 118

A. Heirs' Goals .............................. 118

B. Recent Legislation: House Bill 724 and its Potential Effects ..................................... 119

C. Modern Social, Political, and Cultural Issues....... 119

VI. Conclusion .................................. 122

"Truly the heritage of Texas is as varied and colorful as the land itself. Yet a common denominator has shown at every turn-a prevailing purpose and determination among the settlers, in seeking a new and fuller life, to make the most of the State's unparalleled opportunities. That common denominator has carried happily into the present-and is essential to the fullest achievement in the future!"1

"Indio que labras con fatiga
tierras que de otros duenos son:

$\dagger$ J.D. Candidate, Texas A\&M University School of Law, Spring 2015; B.A. in English 2011, Texas State University.

The Author would like to thank her mother, Debra Cantu for inspiring the topic of this article, Professor Stephen R. Alton for his advisement, Professor Lisa A. Rich for her guidance and revisions, and Mr. John Martin Davis for sharing his expertise. (1962).

1. Jerry Sadler, History of Texas Land, Comm'r of the Gen. Land Office, at ii

DOI: https://doi.org/10.37419/JPL.V2.I1.5 


\author{
¿ignoras tú que deben tuyas \\ ser, por tu sangre y tu sudor? \\ ¿ignoras tú que audaz codicia, \\ siglos atras, te las quitó? \\ ¿ignoras tú que eres el Amo? \\ —iQuién sabe, senor!"
}

\title{
I. INTRODUCTION
}

Five-year old Debbie would sit on a swing in the backyard of her small childhood home, watching her mother, Minerva, hang wet clothing on a line. Minerva would wistfully state a phrase uttered by the family for generations: "Imagine all the things we will be able to do if 'El Niquele'3 ever comes through." When extended family would visit, Debbie would overhear her aunts and uncles discuss a map and a deed to "El Niquele" - a large tract of land in Texas that was stolen from the family many generations ago. Just like their mothers and fathers before them, the family knew the land still belonged to them and they debated how to go about how to reclaim it. But this was in the 1950s and 1960s, when Mexican-American's rights to old land grants in Texas were simply not an issue of interest so the family believed there was no solution. After a few failed attempts to receive legal representation on the matter, the family disregarded their efforts to raise a claim and awaited a change in the political and social atmosphere.

Subsequently, the family rarely spoke of "El Niquele," but still believed their rights should be recognized and a payout of large sums of money should ensue. A few years ago, a distant relative began researching and found an attorney in south Texas who specializes in Spanish and Mexican land grants. This attorney asserts that heirs to these grants should be able to reclaim the mineral estates on the lands once owned by their ancestors. The attorney began a search of the family and over two hundred heirs, including Debbie's family members, of the Jose Domingo Gonzales ("Las Pintas") and Pedro Vela Spanish lands ("El Niquele"), contributed to and joined this new claim to the mineral rights upon the lands once owned by their ancestor.

It has now been over five years since the two hundred plus heirs first began paying their attorney to represent them. The only result of

2. José Santos Chocano, ; Quién sabe!, in Spanish-American Poetry: A Dual Language Anthology 46, (Seymour Resnick ed. trans., Dover Publ'ns, Inc. 1964) (Spanish for "Oh Indian, who labors hard/in fields that someone else owns,/don't you understand, by right/of blood and sweat they should be yours?/don't you understand that brazen greed/ stole them from you, long ago?/don't you know you are the Master?/ Ah, Milord: who knows?").

3. See SpanishDict, http://www.spanishdict.com/translate/nickel (last visited Aug. 7, 2014) (Spanish for "The Nickle."). 
this representation is the recent passage of a bill creating a Commission to research the rights and remedies of the heirs to Spanish and Mexican land grants. ${ }^{4}$ The family grows impatient and has lost five year's worth of money in attorney's fees awaiting answers regarding whether or not they will ever see a payout from "El Niquele." Just as her mother before her, Debbie today will turn to me, her daughter, and say, "Imagine all the things we would be able to do if 'El Niquele' ever comes through."

Land grants issued by Spain and Mexico, in the region which later became the State of Texas, have resulted in a long history of complicated legislation and case law. ${ }^{5}$ The boundary dispute between Mexico and Texas ended with the Treaty of Guadalupe-Hidalgo ("Treaty") in 1848 and resulted in Texas' recognition of the rights of previous landowners. ${ }^{6}$ However, the Treaty did not provide a clear process for handling the competing rights of former landowners and the AngloAmerican settlers who began settling in Texas. ${ }^{7}$ Texas' Constitutional revisions following the Treaty resulted in Texas relinquishing its rights to the mineral estates attached to land, and vesting rights in those landowners given titles by the sovereign of Spain or Mexico. ${ }^{8}$ Since this relinquishment, land grant holders have brought land grant disputes to Texas Courts. The results have been mixed, and resulted in various outcomes as well as some legislative action both on the state and on the federal level. ${ }^{9}$ Thus, over 165 years of complicated title

4. Tex. H.B. 724, 83d Leg., R.S. (2013).

5. See generally HEIRS: Heirs Enforcing Inheritance Rights (2013), http://spanishlandgrants.com/heirs/HEIRS-BROCHURE.pdf; Galen D. Greaser \& Jesús F. de la Teja, Quieting Title to Spanish and Mexican Land Grants in the Trans-Nueces: The Bourland and Miller Commission, 185 -1852, 95 Sw. Hist. Q. 445 (Apr. 1992); Federico M. Cheever, A New Approach to Spanish and Mexican Land Grants and The Public Trust Doctrine: Defining the Property Interest Protected by the Treaty of Guadalupe-Hidalgo, 33 UCLA L. Rev. 1364 (June 1986); Article, Validity of Certain Spanish Land Grants in Texas, 2 Tex. L. Rev. 435 (1924); The Land Grant Justice Association, http://www.landgrantjustice.org/mission.html (last visited 2013); SPANISH AND MEXICAN LAND GranTs, spanishlandgrants.com (Last updated 2013); State v. Ballí, 190 S.W.2d 71 (Tex. 1944); State v. Gallardo, 166 S.W. 369 (Tex. 1914); Fremont v. United States, 58 U.S. 542 (1854).

6. HEIRS, supra note 5, at 2; see also Treaty of Peace, Friendship, Limits and Settlement With the Republic of Mexico, U.S.-Mex., Feb. 2, 1848, 9 stat. 922, 1848 WL 6374 [hereinafter Treaty]; J.J. Bowden, Spanish and Mexican Land Grants in the Chihuahuan Acquisition, Texas Western Press, 3 (1971); Florence Johnson Scott, Royal Land Grants North of the Rio Grande 1777-1821, x (1969).

7. Greaser \& de la Teja, supra note 5, at 446.

8. HEIRS, supra note 5, at 3, Greaser \& de la Teja, supra note 5, at 463.

9. See generally Gallardo, 166 S.W. at 369; Balli, 190 S.W.2d at 71; Fremont, 58 U.S. 542; Act of June 13, 2013, 83rd Legs., R.S., ch. 878, 2013 Tex. Gen. Laws 2223; Jon Michael Haynes, What Is It About Saying We're Sorry? New Federal Legislation and the Forgotten Promises of the Treaty of Guadalupe Hidalgo, 3 SCHOLAR 231 (2001). 
claims have yet to result in legislative directives or court actions creating an efficient process for adjudicating land grant disputes. ${ }^{10}$

Spanish and Mexican land grant heirs continue to bring claims to establish their rights to the mineral estates with hopes of collecting royalties from the oil and gas extracted from the lands previously owned by their ancestors. ${ }^{11}$ My family's land grant is one among hundreds of Spanish and Mexican land grants that were never recognized by the State of Texas. ${ }^{12}$ Establishing these rights has become more important because of the increased drilling production in the last few years, especially since shale drilling technology has made it possible to extract oil and gas from previously unprofitable areas. ${ }^{13}$ In addition, there are large sums of money in the form of royalties that go unclaimed every year because of unknown mineral estate owners. ${ }^{14}$ The recent passage of House Bill 724 ("HB 724") in the Texas legislature, which created a Commission to find land grant heirs and determine possible royalty payouts for mineral rights, may result in further determinative legislative action. ${ }^{15}$ Currently, determining heirship and rights is still a complicated, uneven process. ${ }^{16}$

This Comment discusses the history of Spanish and Mexican land grants in Texas and the complicated issues of: (1) recognizing the rights of original land grant owners; and (2) distinguishing what remedies, if any, shall be given to their heirs. Part II provides background of Spanish and Mexican land grants in Texas, including the provisions included in the Treaty of Guadalupe-Hidalgo, and the underlying cultural, political, and social issues. Part III discusses the history of general land grant case law and mineral estate case law in Texas. Part IV discusses the current obstacles that heirs face in bringing ancient land grant claims, which are subject to the current property laws in Texas. Finally, Part V explores the possible future for land grant disputes including the recent passage of $\mathrm{HB} 724$, the current goals of heirs

10. See Andrew Walker, Mexican Law and the Texas Courts, 55 BAYLOR L. ReV. 225, 233-34, 24 -42 (2003); see also John MacCormack, Land-Grant Heirs See Gold in Old Mineral Royalties, San Antonio Express-News (Sept. 15, 2013), http://www. expressnews.com/news/local/article/Land-grant-heirs-see-gold-in-old-mineral-royalties-4815134.php; Spanish and Mexican Land Grants, supra note 5; Land Grant Justice Association, supra note 5.

11. Spanish and Mexican Land Grants, supra note 5; Land Grant Justice Association, supra note 5; Haynes, supra note 9, at 232 ("Recently in Texas, MexicanAmerican families have begun to fight for the return of their ancestral lands. . ..").

12. Spanish and Mexican Land Grants, List of Land Grants with Good Recovery Potential, http://www.eileenmckenziefowler.com/Grants-Indicating-Net-Mineral-Estate.cfm (last visited 2013).

13. Jennifer Hiller, Eagle Ford and Energy: Unclaimed Mineral Royalties Increasing, SAn Antonio Express-News (Aug. 5, 2013, 1:15 PM), http://www.expressnews. $\mathrm{com} /$ news/energy/article/Unclaimed-mineral-royalties-increasing-4704339.php.

14. Id.

15. Tex. H.B. 724.

16. MacCormack, supra note 10 , at 2. 
seeking recognition of their rights, and competing arguments on the fulfillment of those goals.

\section{The History of Spanish and Mexican Land Grants in TEXAS}

\section{A. The History of Texas Lands}

Texas has a history unique from other states that provides for interesting and complicated property disputes, which still affect real property ownership today. ${ }^{17}$ The majority of the land that is considered part of the State of Texas today was originally owned by Spain. ${ }^{18}$ Spanish rule extended into Mexico as well, but Mexican citizens eventually revolted, and Mexico became the sovereign over all the previously Spanish owned lands. ${ }^{19}$ Although the Mexican government allowed Anglo-Americans to settle on their land under contracts, disputes over land ownership resulted in a revolution and the formation of the Republic of Texas, which governed the land north of the Rio Grande River. ${ }^{20}$ By the end of 1845, the United States annexed the Republic of Texas and that land is now the State of Texas. ${ }^{21}$

\section{Spanish and Mexican Sovereignty}

Texas land ownership rights began with land grants that were issued by the Spanish crown between 1750-1810, and Mexican land grants that were given between $1810-1836 .^{22}$ Land grants issued by Spain were called Porciones, which were rectangular strips of land located along the Rio Grande River. ${ }^{23}$ When Spain ruled Texas, territory south of the Nueces River was the most populated. ${ }^{24}$ Other tracts of land were conveyed to "influential" persons just north of the Por-

17. See Sadler, supra note 1, at ii, 19-22.

18. Id. at $2-3$.

19. Id. at $4-5$.

20. Id. at 8 .

21. Id. at 12 .

22. HEIRS, supra note 5, at 2; see also Terry I. Cross, Why Texas Titles are Different, 4 Rocky Mtn. Min. L. Inst. Paper No. 16, 3-4 (2007) (Texas has existed as a political unit under four different sovereigns); Scott, supra note 6, at ix ("Royal grants of land from the King of Spain were made in the Lower Rio Grande beginning in 1767.").

23. HEIRS, supra note 5, at 2; see also Scott, supra note 6, at ix ("The porcion grants had been given a number but these larger grants were named, sometimes for a saint, other were taken from some physical or natural characteristic such as a prairie or pasture, or from a mott of trees, or from a dry lake or arroyo, or from some event or happening. Such names have survived both through verbal usage and on current maps, and the names of the original grantees are preserved in abstracts and other legal records."); Land Grants, TeXAs General LAND OfFICE, http://www.glo.texas. gov/what-we-do/history-and-archives/the-collection/land-grants/ (last visited Mar. 22, 2014) (". . . land titles issued by Spain and Mexico from 1720 to 1836;" "The Spanish Collection is the primary source of documentation for land distribution in Texas prior to $1836 . ")$.

24. Walker, supra note 10, at 232. 
ciones and along the coast. ${ }^{25}$ These original land grants were normally conveyed without any mention of the minerals associated with the land so mineral rights were retained by the crown of Spain or Mexico. ${ }^{26}$

French and Spanish explorers fought for settlement and claim to Texas land beginning in $1685 .{ }^{27}$ Spain established missions with a primary settlement in San Antonio by 1718 and the first colonies were established by $1731 .{ }^{28}$ Anglo-American settlers began moving into the region by 1779 , but their numbers were less than 3,000 by 1820 when Moses Austin received a colonization contract with Spain. ${ }^{29}$ Austin, and later his son, Stephen F., were given authority by the Spanish crown to settle three hundred Anglo-American families in the Texas area. ${ }^{30}$ By 1822, revolution in Mexico resulted in a new Mexican government. ${ }^{31}$ Stephen F. Austin's efforts to renew the contract of his colony proved successful and even resulted in a new colonization Act allowing more settlers into Texas. ${ }^{32}$

Stephen F. Austin increased his efforts to bring more Anglo-American colonists into Texas and offered incentives to potential land purchasers, such as no taxes for six years, in order to increase interest. ${ }^{33}$ In 1823, Austin appointed a land commissioner to begin issuing actual land titles to the new settlers. ${ }^{34}$ Austin and other "empresarios" 35 were given contracts by the Mexican government to settle more land with Anglo-Americans and by 1835, the time Spain was no longer the sovereign, about one-seventh of the Texas area was owned by these private settlers. ${ }^{36}$ Within a few years, the Anglo-American population increased from 3,000 to almost 30,000 by $1835 .{ }^{37}$

\section{The Republic of Texas}

Over the years, tensions rose and controversy between these new settlers and Mexican land laws resulted in revolution and the ten-year

25. HEIRS, supra note 5, at 2.

26. $I d$. at 3 .

27. Sadler, supra note 1 , at 3.

28. Id.

29. Id. at 4.

30. Id.

31. Id. at $4-5$.

32. Id.

33. Sadler, supra note 1 , at 5 .

34. Id.

35. Id. at 5 ("Empresarios" were Anglo-Americans who signed contracts with the Mexican government to colonize certain, specified areas of Mexican land with Anglo American settlers.).

36. Id. at 6-7; see also, Bowden, supra note 6, at 151 (The change in sovereignty from Spanish to Mexican rule resulted in the recognition of all valid Spanish issued land grants, and private landowners were not affected by the change in government rule.).

37. Sadler, supra note 1 , at 5 . 
reign of the Republic of Texas. ${ }^{38}$ The 1836 Lone Star Republic Constitution created the General Land Office and the new Commissioner began securing land records for all the Anglo-American settlers. ${ }^{39}$ These records were used to appropriate 30 million acres of public domain lands, which were then issued in the form of "Headrights." 40 Headrights were conveyances of land issued to the heads of families and single men. ${ }^{41}$ Under the Republic of Texas, more empresarios received contracts to settle land all over Texas. ${ }^{42}$

\section{The State of Texas}

The United States began negotiations concerning the annexation of the Republic of Texas in $1844 .{ }^{43}$ By December 29, 1845, Texas officially became a state under the jurisdiction of the United States. ${ }^{44} \mathrm{Be}$ cause the United States Congress did not want to incur debt by paying for Texas' land, the State of Texas retained its public lands and continued to recognize valid titles that were issued by Spain, Mexico, and the Republic of Texas. ${ }^{45}$ The State of Texas began issuing various types of grants to: individuals; veterans; railroad, highway, and water canal construction companies; capitol building construction projects; and public schools. ${ }^{46}$ Through these grants, the State of Texas ended up selling over $90 \%$ of its land but did not hold on to the mineral rights. ${ }^{47}$ Finally, in 1895, The Mineral Act authorized mineral permits to be issued to private surface owners. ${ }^{48}$

\section{The Treaty of Guadalupe-Hidalgo}

Under Texas law, property rights issued by a prior sovereign were not divested when Texas became a state, and the establishment of the new State's government gave Texas the right to eminent domain and to change the laws relating to acquiring property within its territory. ${ }^{49}$ However, the Treaty of Guadalupe Hidalgo officially ended the border dispute between Mexico and the State of Texas in 1848 and resulted in the State's recognition of the land grants conveyed by Spain and Mexico. ${ }^{50}$ In 1860, the Texas Legislature gave authority to the district courts to validate all land grant estates issued by the prior sov-

38. Id. at $8-9$.

39. Id.

40. Id. at 9 .

41. Id.

42. Sadler, supra note 1 , at 11.

43. $I d$.

44. Id. at 12 .

45. Id

46. Id. at $14-19$.

47. Sadler, supra note 1, at 19 (the state's later adoption of the common law assured that the state would retain gold and silver only).

48. Id. at $19-20$.

49. 47 Tex. Jur. 3d International Law § 3 (2013).

50. HEIRS, supra note 5, at 2; see also Treaty, supra note 6. 
ereigns. ${ }^{51}$ Article VIII of the Treaty provided that Mexicans who were already "established in territories previously belonging to Mexico . . . shall be free to continue where they now reside." 52 Article VIII also established that "the present owners, the heirs of these, and all Mexicans who may hereafter acquire said property by contract, shall enjoy with respect to it guaranties equally ample as if the same belonged to citizens of the United States." 53 The Treaty also gave Mexicans residing within the new boundaries of Texas the choice to decide whether they would remain Mexican citizens or take on United States citizenship. ${ }^{54}$ Despite the Treaty's stipulations, boundary disputes continued up until $1963 .^{55}$

Essentially, the Treaty provided that if a land grant was valid under the Mexican government before the time the boundaries of Texas were decided, December 19, 1836, and that land was within Texas territory, it was protected under the Treaty of Guadalupe Hidalgo. ${ }^{56}$ This also meant that if a Spanish or Mexican land grant was conveyed after 1836, the State of Texas will not recognize it. ${ }^{57}$

Because Texas retained its public land when it became a state, it is left to the State to determine the legality of all previous claims to land within its borders. ${ }^{58}$ Often, the State had difficulty validating claims because grants were incomplete, defective, or fraudulent. ${ }^{59}$ Interestingly, many of the claims related to land in the southern part of Texas are now settled. ${ }^{60}$

\section{Historical Land Grant Commissions}

In the years following the Treaty of Guadalupe Hidalgo, it became clear that the Treaty did not provide a neat process for protecting property rights of original landowners. ${ }^{61}$ Also, the loss of documenta-

51. HEIRS, supra note 5, at 2.

52. Treaty, supra note 6 , at 4.

53. Id. at 5; see also Bowden, supra note 6, at xii ("[T]he property rights of Mexicans who remained in the affected area, whether or not they elected to retain their Mexican citizenship, were to be protected to the same extent as those of citizens of the United States.").

54. Treaty, supra note 6 , at 5.

55. Walker, supra note 10, at 237.

56. 60 Tex. Jur. 3d Public Lands § 20 (2013).

57. Id.; see also, Bowden, supra note 6, at 110-12, 113-14 (the Rafael Ruelas Grant was granted to Ruelas by a Mexican judge in 1848 and when Ruelas' son-inlaw, after purchasing the land, brought his land grant claim to court, it was found that because it was issued by Mexico after Texas had become a state, the grant was invalid; The Luis Cuaron Grant was issued by a Mexican Judge in 1847 and was therefore declared invalid by a Texas court.).

58. Greaser \& de la Teja, supra note 5, at 463 (see also discussion on Land Grant Commissions, in section $v$. below).

59. 3 Aloysius A. Leopold, Texas Practice Series: Land Titles and Title Examination $\$ 1.7$ (3d ed. 2013).

60. $I d$.

61. Greaser \& de la Teja, supra note 5, at 446. 
tion of land ownership from theft, poor record keeping, and the confusion caused by contradictory grants made processing claims even more difficult. ${ }^{62}$ Once the State of Texas began exerting its control over the region, new claims were raised by owners of Republic of Texas Headright certificates, which had been filed with the Texas General Land Office. ${ }^{63}$ Under international law principles, the Treaty protected the interests of Mexicans in the areas now within Texas boundaries. ${ }^{64}$ Current landowners, Anglo and Mexican alike, were opposed to a commission created by Governor Bell in 1849 to investigate land titles because they were concerned about the diminution of their titles. ${ }^{65}$ However, those landowners who supported the Commission, made an effort to pledge their loyalty to the State of Texas, motivated by the hopes of quieting false titles. ${ }^{66}$

Governor Bell appointed William H. Bourland and James B. Miller as commissioners of the Bourland and Miller Commission ("Bourland Commission"). ${ }^{67}$ The Bourland Commission was created to determine whether grants claimed by heirs were perfected under the laws of the previous sovereign and if they were not, whether they would have been if Texas had not taken over. ${ }^{68}$ The commissioners followed a set procedure in making determinations: petitions were considered if the documentation presented by claimants included the location of the land, a survey of the land, proof that the land had been occupied continuously - save for periods of time involving Indian occupation-and evidence that the land had been used or cultivated in some way. ${ }^{69}$ The Commission submitted reports to the legislature after gathering information on all claims submitted and found that 234 of the claims were perfect or perfectible. ${ }^{70}$ This Commission was successful in validating claims to land that were actually made, but it was not able to help others make a valid claim to land because of loss of land due to corruption, Indian violence, lack of legal resources, and the like. ${ }^{71}$ The Commission did establish ownership for most of the Spanish-speaking owners who would have been able to establish a claim under Spanish

62. Id. at $446-47$.

63. Id. at 447; see also, Cross, supra note 21, at 5 ("Grants during the Republic were made under four different systems: (a) the impresario system; (b) headrights; (c) pre-emption; and (d) homestead.").

64. Greaser \& de la Teja, supra note 5, at 447.

65. Id. at $449-52$.

66. Id.

67. Id. at 454 .

68. Id. at 457 (the Bourland Commission is also referred to as the Bell Commission. Bourland was the primary commissioner responsible for locating and validating land grants); Bowden, supra note 6, at 95-96 (showing that the Bell Commission is also referred to as the Bourland Commission; Bourland was the primary commissioner responsible for locating and validating land grants).

69. Greaser \& de la Teja, supra note 5, at 458.

70. Id. at 459 .

71. Walker, supra note 10 , at 241-42. 
or Mexican law. ${ }^{72}$ After this Commission, subsequent commissions investigated claims in other areas of the State. ${ }^{73}$

While representing an Anglo-American Texas settler in the 1850s, attorney Josiah F. Crosby became State Representative and instigated the passage of an Act, which created the Rio Grande Commission. ${ }^{74}$ Like the Bourland Commission, the Rio Grande Commission was designed to investigate Spanish and Mexican land grants, but specifically in certain counties not covered by the Bourland Commission. ${ }^{75}$

\section{B. Mineral Estates in the State of Texas}

When Texas became a Republic-and later when it became a State-it held the mineral rights when land was conveyed, reserving the mineral estate to the State's control. ${ }^{76}$ In 1840 , the common law was adopted by Texas but did not apply expressly to determinations about mineral rights. ${ }^{77}$ However, the new State Constitution of 1866 returned the right to mineral estates to surface owners and later Constitutions and cases continued to implement mineral estates in favor of surface estate owners. ${ }^{78}$ After 1866 , cases construed the relinquishment of mineral rights to landowners narrowly so that it favored the State; specifically, all State conveyances of public lands beginning in 1912 reserve the mineral estates for the State. ${ }^{79}$

To remedy the unanticipated loss of wealth from oil and gas revenue, the State later enacted laws allowing royalty and bonus payments through mineral leases for oil, coal, and natural gas. ${ }^{80}$ Many portions of land all across the State were designated to public schools and managed by the State. ${ }^{81}$ Texas was able to lease over half a million acres in mineral estates on these public school lands and began collecting royalties from across the State. ${ }^{82}$ Controversy surrounded mineral de-

72. $I d$. at $249-50$.

73. Greaser \& de la Teja, supra note 5, at 460-61; Bowden, supra note 6, at 96.

74. Bowden, supra note 6, at 95-96.

75. Id. at 96 .

76. HEIRS, supra note 5, at 3; see also Peter L. Reich, Western Courts and the Privatization of Hispanic Mineral Rights Since 1850: An Alchemy of Title, 23 Colum. J. ENVTL. L. 57, 84 (1998); Cowan v. Hardeman, 26 Tex. 217, 224 (1862) (finding that the Act of 1840 retained mineral rights in sulphur and "minerals of every description" to the state in repeal of prior Mexican law and for the protection of the interest of the state).

77. HEIRS, supra note 5 , at 3 .

78. Reich, supra note 73, at 84-85; State v. Parker, 61 Tex. 265, 268 (1884) (“. . . all mines and mineral substances, including salt lakes, etc., now of right belong to the owner of the soil. ..").

79. Reich, supra note 76, at 85; Cox v. Robinson, 150 S.W. 1149, 1155-56 (Tex. 1912); Schwarz v. State, 703 S.W.2d 187, 189-91 (Tex. 1986) (finding that coal and lignite specifically were not included in the Act of 1840; therefore, the state owned those minerals).

80. Sadler, supra note 1 , at 20.

81. Id.

82. Id. 
velopment of the Gulf area along the coast until 1960 when the State finally retained ownership of those mineral estates as well. ${ }^{83}$

\section{Historical Social, Political, and Cultural Issues}

Texas and Mexico continued to be dependent upon each other even after Texas became a state, but the conflicts of culture and legal systems created a control issue when it came to establishing proper ownership of land. ${ }^{84}$ The people populating Texas land during Mexican rule did not experience political miscommunication until Englishspeaking people settled in Texas. ${ }^{85}$ When Mexico was still the sovereign in Texas, the Mexican government allowed Anglo-Americans to settle in Texas as Mexican citizens which resulted in conflicts between cultures and ideologies of English-speaking citizens and Spanishspeaking citizens. ${ }^{86}$ These conflicts eventually led to the Texas Revolution and the establishment of the Republic of Texas. ${ }^{87}$

Texas has a unique legal atmosphere thanks to the geographic and political connection Texas has maintained with Mexico. ${ }^{88}$ Applying Mexican law allowed white immigrants title to lands which were once subject to the laws of Spain and Mexico. ${ }^{89}$ Hispanic and non-Hispanic immigrants both benefited from Mexican law favoring their titles. ${ }^{90}$ As new leaders moved into Texas, Mexican law was associated with an overthrown government and differing cultural groups began to clash. ${ }^{91}$ New residents of Texas felt no need to adapt to Mexican law once Texas became a state..$^{92}$

Varying outcomes of land grant disputes over the years offer little guidance for how Spanish and Mexican land grant holders' disputes would fare today. The Commissioner of the General Land Office of Texas in 1962, Jerry Sadler, concluded in his brief history of Texas land, that although some mineral revenues are received by the State through the Public School Fund, mineral estate ownership in Texas for the most part was, and still is, unclear. ${ }^{93}$ Commissioner Sadler aptly concludes: "Simple dedication 'to the public good' is insufficient, and the Legislature is now struggling with the challenge. The four-million odd acres constitute another frontier. They will extend the story of Texas lands into still another era, leaving more to be written." 94

83. Id. at 21.

84. See Walker, supra note 10, at 231.

85. Id. at $232-33$.

86. Id. at 233-34.

87. Id. at 234 .

88. Id. at 239.

89. Walker, supra note 10 , at 240.

90. Id. at 240-41.

91. Id. at 246.

92. Id.

93. Sadler, supra note 1 , at 21.

94. Id. at 21-22. 


\section{Texas Land Grant Disputes Case History}

\section{A. General Land Claims}

Land disputes over the years have included both claims to title of land generally and claims for mineral rights. Historical case law in Texas regarding Spanish and Mexican land grants primarily covers disputes over the actual land and not disputes over rights to mineral estates. ${ }^{95}$

For example, Texas acquired a portion of the Mexican State of Chihuahua through the Compromise of $1850 .{ }^{96}$ Texas acquired 13,445,000 acres of land with this Compromise and later acquired another $3,219,000$ acres from the Gadsden Treaty in $1853 .{ }^{97}$ Twenty-six private land claims for land in this area were brought to Texas courts after the acquisition of Mexican land. ${ }^{98}$ Owners who were "educated, influential, wealthy," or who owned a substantial amount of land brought the majority of these land grant claims. ${ }^{99}$ The other land grant claims were brought by colonies consisting of multiple Mexican families that resided on and cultivated the land. ${ }^{100}$ Colony land grants often resulted in the Texas government paying the Mexican families to move into new boundary lines of the Chihuahuan state of Mexico partially because such families declared their loyalty to Mexico and not to Texas. ${ }^{101}$

In the early 1800s, the Canutillo Grant provided a portion of land to thirty different landowners who later petitioned for recognition of their Mexican grants by their town official. ${ }^{102}$ Recognition was given so long as the owners entered upon and cultivated the land in question. ${ }^{103}$ These landowners brought claims, and a special commission was appointed to survey and set the boundary lines for the exact portion of land to be given to the petitioners. ${ }^{104}$ Once this was complete, the petitioners agreed to the allotted portion and entered the land in 1823. ${ }^{105}$ In 1833, Apache Indians drove landowners off their land and the land was subsequently settled by James W. Magoffin in $1850 .{ }^{106}$

95. See generally State v. Ballí, 190 S.W.2d 71 (Tex. 1944); State v. Gallardo, 166 S.W. 369 (Tex. 1914); Cortina v. P.I. Corp., 385 S.W.3d 613 (Tex. App.-Corpus Christi 2012, no pet. h.).

96. Bowden, supra note 6 , at 1 .

97. $I d$. at $1-3$.

98. Id. at 3.

99. See Bowden, supra note 6 (results for these disputes had varying results, and depended mostly on whether or not the original grant was recognized by the prior sovereign and if it was granted by Mexico before Texas became a state).

100. Id.

101. Id. at 48 .

102. $I d$. at 94 .

103. Id.

104. Bowden, supra note 6 , at 94 .

105. Id.

106. $I d$. 
The owners of the Canutillo Grant acted quickly, and in 1852, they hired attorneys who agreed with Magoffin to convey a one-third interest in the grant once it was confirmed by the State of Texas. ${ }^{107}$ However, the Bourland Commission was not examining Spanish and Mexican land titles in the area where the Canutillo Grant land was located. ${ }^{108}$ Magoffin hired District Attorney Josiah F. Crosby to represent his one-third interest and offered Crosby a one-half interest as payment for his services. ${ }^{109}$ Fueled by this incentive, Crosby won State Representative the following election and was the instigator of the passage of an Act creating the Rio Grande Commission which was to investigate Spanish and Mexican land grants in several counties including El Paso County, where the Canutillo Grant was located. ${ }^{110}$

The Rio Grande Commission recommended recognition of only some of the land grant claims it had investigated and submitted its report to the governor. ${ }^{111}$ The governor then passed the report on to the Texas Legislature, which passed a bill allowing relinquishment of nearly 900,000 acres of land, but the governor vetoed the bill because it included land which was not a part of the Rio Grande Commission's recommendations. ${ }^{112}$ The Canutillo Grant was one of the tracts of land recommended by the Commission to be relinquished, and the owners of the Grant, "sought special relief legislation" and received it with the passage of a bill in 1858 relinquishing their land and other land grant tracts. ${ }^{113}$ The law did not describe the exact metes and bounds of the land that was relinquished. ${ }^{114}$ Instead, it only gave the names of the land grants, and the second half of the law required the land to be surveyed, and directed the General Land Office to issue patents upon receipt of the survey field notes. ${ }^{115}$ Subsequent disputes over the proper surveying of the land, as well as Railroad Commission land use allowances, altered the boundary lines of the Canutillo Grant up until $1866 .{ }^{116}$

The Canutillo Grant is one example of the more than two dozen land grant claims brought by original landowners after the acquisition of Mexican lands in the early 1850s. ${ }^{117}$ Despite the efforts of the Commissioners involved in the Bourland and Rio Grande Commissions, not all Spanish and Mexican land grant holders brought their

107. $I d$.

108. $I d$.

109. Bowden, supra note 6, at 94.

110. Id. at 96 .

111. $I d$.

112. $I d$. at $96-97$.

113. Id. at 97, 106.

114. Bowden, supra note 6, at 106.

115. Id.

116. Id. at 97-101.

117. Id. at 74, 94-96. 
claims, resulting in later-realized rights by heirs and transferees of original land grant owners to this day.

In State v. Gallardo, landowners brought a claim for land that was granted to the town of Reynosa by the Spanish crown in 1767 and was located just north of the Rio Grande River. ${ }^{118}$ By 1836, the land was located in the Mexican state of Tamaulipas and transferred to Gallardo in $1841 .{ }^{119}$ The State of Texas claimed that because the land belonged to Mexico when title was passed, the State of Texas actually owned it as public domain. ${ }^{120}$ Gallardo argued that the purchasers from whom he bought the land had acquired title before Texas became a state and therefore, the court should give effect to Mexican law which, would give Gallardo full title. ${ }^{121}$ The Court found that the title in question was recognized by the Mexican government at the time the land became a part of Texas and was therefore subject to protection under the Treaty of Guadalupe Hidalgo. ${ }^{122}$ The Court held that the continuous occupation of the land by the private owner, and recognition of the private owner's grant by the Mexican sovereign, perfected title under the State of Tamaulipas. ${ }^{123}$ Texas's failure to claim the land and control it created mitigating circumstances, which gave Gallardo the stronger claim. ${ }^{124}$

In 1921, in Kenedy Pasture Co. v. State, several parties asserted title to divided land encompassing a total of 30,000 acres. ${ }^{125}$ Mexican heirs claimed title under a land grant called Santa Rosa de Abajo issued to their ancestor from the Mexican government. ${ }^{126}$ The Supreme Court of Texas affirmed the trial court's ruling that the land grant was void because the Governor of the Mexican State of Tamaulipas issued it in 1848, after Texas became the new sovereign over that territory. ${ }^{127}$ The Court reasoned that a prior sovereign could no longer grant title to land it no longer owned. ${ }^{128}$ On December 19, 1836, the Republic of Texas claimed that its territory extended to the Rio Grande River and therefore, any title granted by Mexico after that date could not be considered valid in Texas Courts. ${ }^{129}$ The Court also found that the Treaty of Guadalupe Hidalgo only protected those titles granted by Mexico before December 19, 1836, and those titles which were good in equity prior to that date. ${ }^{130}$ Although the land grant was found

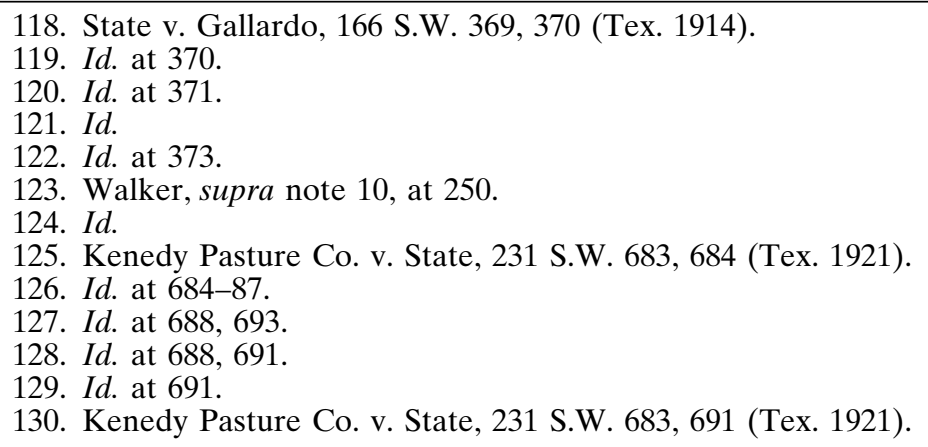


void, the Court concluded that the heirs still had equitable title because the evidence showed that the Governor of Texas recognized the title and the original owner remained in lawful possession of the land until 1850 or $1860 .{ }^{131}$ However, the Court held that equitable title to land that had remained vacant and unclaimed by the original owner and his heirs for over seventy years, would not trump title conveyed by the State of Texas to innocent landowners currently in rightful possession. ${ }^{132}$

In State v. Ballí, claimants were conveyed land, which is now known as Padre Island, from Padre Nicholas Ballí. ${ }^{133}$ The case included several related parties, including oil and real estate companies that were interested in the land. ${ }^{134}$ The State argued that the claimants had relinquished title when they failed to survey the land by the appropriate date in compliance with the Relinquishment Act and the Texas Constitution. ${ }^{135}$ The Court concluded in Balli that using a State Constitutional provision to nullify Mexican and Spanish grants that had not been surveyed accordingly under Texas law, would raise unnecessary equal protection and due process questions. ${ }^{136}$ If the Court had decided differently, Spanish and Mexican titles would have been considered void if they were not recorded or archived, but this requirement was not present in the previous Constitution and no adequate time was allowed for compliance so the Court found the State Constitution provision unconstitutional. ${ }^{137}$ The Court's decision in Balli was the first case to apply Mexican law to land disputes more liberally. ${ }^{138}$ The decision in Balli resulted in subsequent Courts applying a more accurate analysis to Mexican land grant disputes. ${ }^{139}$

In 1947, in Amaya v. Stanolind Oil \& Gas Company, Mexican citizens with a valid land grant issued to their ancestor from the kingdom of Spain, claimed an interest in lands owned by Stanolind Oil and Gas. ${ }^{140}$ The appellants asserted that the Treaty of Guadalupe-Hidalgo protected their original title even against later enacted Texas laws applying to adverse possession, statute of limitations, and forfeiture. ${ }^{141}$ The Court examined the language within the Treaty of Guadalupe Hidalgo and concluded that the Treaty did not excuse Mexican citizens with valid land grants from the subjection of Texas laws. ${ }^{142}$ The Court

131. Id. at 693 .

132. Id. at 694 .

133. State v. Ballí, 190 S.W.2d 71, 73 (Tex. 1944).

134. Walker, supra note 10 , at 260.

135. Ballí, 190 S.W.2d at 83.

136. Harold Hoffman, Texas Land Titles and Vested Rights, 25 Tex. L. Rev. 508, 526 (1947).

137. Id. at 526-27.

138. Walker, supra note 10 , at 259.

139. Id. at 260-61.

140. Amaya v. Stanolind Oil \& Gas Co., 158 F.2d 554, 555 (5th Cir. 1946).

141. Id.

142. Id. at 557. 
also found that the Treaty guaranteed that Mexican land grants would be respected but it did not guarantee protection against the loss of land due to adverse possession, foreclosures, and similar acts. ${ }^{143}$ The Court reasoned that the Treaty of Guadalupe Hidalgo, in recognizing prior grants, was intended to extend the same respect to land claims raised by Mexican citizens as it did to land claims raised by citizens of the United States. ${ }^{144}$ The Court held that the appellants were subject to the current property laws of Texas and that their claim to the land in question was time barred by the State's statutes of limitation. ${ }^{145}$

The Balli decision resulted in many more claims to the land on $\mathrm{Pa}-$ dre Island, including a 2012 dispute over an interest in land between P.I. Corporation and other Ballí descendants. ${ }^{146}$ The Cortinas (Ballí descendants), argued that the land conveyed through a guardian's deed from their ancestor to third party Grisante, was void because the sale took place after Texas became a state in 1846 and therefore, Mexican law no longer had authority over Texas lands. ${ }^{147}$ However, the Court recognized that "Texas courts apply a presumption in favor of ancient judgments, particularly those involving land titles." 148 The Court reasoned that the land transaction in dispute was between individual Mexican citizens and not between the state of Mexico and an individual. ${ }^{149}$ Therefore, when a state has personal jurisdiction over individuals, it has authority over those individuals even if their dispute involves land in another state. ${ }^{150}$ In this case, the Court affirmed summary judgment in favor of P.I. Corporation because it found that Mexico had personal jurisdiction over Cortinas's ancestor and Grisante because they were individual Mexican citizens. ${ }^{151}$

The provisions of the Treaty of Guadalupe Hidalgo shaped the outcome of the first one hundred years of land grant cases. Texas legislators realized that recognition of valid Mexican grants required by the Treaty was not simple and created two commissions designed to validate or invalidate claims raised by Mexican citizens. ${ }^{152}$ The Texas Supreme Court considered land grants valid if they were granted and recognized by Mexico prior to the date that Texas became a Republic. $^{153}$ Although a land grant's validity was partly based on the laws of the prior sovereign, land grant owner's rights were determined not to subvert the rights of landowners in rightful possession of the land

143. Id. at 558 .

144. Id. at 557-58.

145. See Amaya v. Stanolind Oil \& Gas Co., 158 F.2d at 558-59.

146. Cortina v. P.I. Corp., 385 S.W.3d 613, 617 (Tex. App.-Corpus Christi 2012, no pet. h.).

147. Id. at 615 .

148. Id. at 617 .

149. Id.

150. $I d$.

151. Cortina, 385 S.W.3d at 617.

152. See Bowden, supra note 6, at 95-96.

153. Kenedy Pasture Co. v. State, 231 S.W. 683, 684 (Tex. 1921). 
under Texas property law. ${ }^{154}$ More recently, the Court determined that Mexican law would apply when citizens of Mexico were the original parties in a land grant transfer. ${ }^{155}$

\section{B. Mineral Estate Claims}

Texas case law history concerning land grant claims to mineral estates is less extensive and offers little guidance for land grant heirs who want to raise mineral estate claims today.

In 1986, in Schwarz v. State, private landowners attempted to claim ownership to coal and lignite extracted by a construction company to whom Schwarz had given a mining lease. ${ }^{156}$ However, the Schwarzs's predecessors had purchased the land from the State of Texas' General Land Office so the Court found that the dispute was between the State and a private landowner. ${ }^{157}$ The Court reasoned, based on prior case law and legislation, that the intent of the legislature in granting land to a private landowner was to retain the mineral estate. ${ }^{158}$ The Court held that all the lignite under the Schwarzs's tract of land belonged to the State of Texas. ${ }^{159}$

In 2008, in Kerlin v. Sauceda, more Ballí heirs brought a claim against an attorney for fraud alleging he concealed their royalty rights in Padre Island land and conveyed those rights to himself. ${ }^{160}$ Heirs to one portion of the original Ballí grant sought legal assistance (in discovering their legal rights to the land in question) from the attorney. ${ }^{161}$ The attorney informed the heirs that they did have rights to the land and mineral interests. ${ }^{162}$ He then fraudulently, and without permission from the heirs, took the eleven signed deeds from the heirs and conveyed 20,000 acres of land and related mineral interests to himself during settlement. ${ }^{163}$ The attorney sold these interests and twenty-four years later, another heir, Sauceda, contacted the attorney about the deeds he had created at the settlement for the heirs and the attorney informed her that the deeds were invalid. ${ }^{164}$ Eight years later, 275 heirs sued the attorney for fraud and won unpaid royalty interests in the mineral estate. ${ }^{165}$ However, the Supreme Court of Texas reversed the judgment because the heirs were time barred by

154. See Amaya v. Stanolind Oil \& Gas Co., 158 F.2d 554, 558-59 (5th Cir. 1946).

155. Cortina, 385 S.W.3d at 617.

156. Schwarz v. State, 703 S.W.2d 187, 187-89 (Tex. 1986).

157. Id. at 189 .

158. Id. at 189-91.

159. Id. at 191.

160. Kerlin v. Sauceda, 263 S.W.3d 920, 921-22 (Tex. 2008).

161. Id. at 922 .

162. Id. at 923.

163. Id.

164. Id. at 924.

165. Id. 
the statute of limitations from bringing the fraud claim against the attorney. ${ }^{166}$

Mineral estate case law provides that the State will retain the mineral rights when it is found that the State has conveyed land to private owners. ${ }^{167}$ It is yet to be seen whether Texas Courts will recognize heirs' rights to mineral estates on land once owned by their ancestors and whether or not an award is available.

\section{Current Obstacles and Rights for Heirs}

The underlying issues at the time Texas established its territory and entered into a friendly agreement with Mexico are still issues today. The Bourland Commission and the Rio Grande Commission established land grants for Mexican title holders who were able to come forward either because they were well-connected or wealthy; the Commission did not help those who did not have the means to make a claim to their rightfully owned land. ${ }^{168}$ The clashing of Mexican and American cultures has continued, ${ }^{169}$ is still present today, and may account for why heirs to unclaimed land grants have just recently begun to come forward with documentation their families have possessed for decades. This recent and building interest of Mexican-American citizens laying claim to their ancestor's property may not play out the way heirs anticipate and part of this has to do with the clash of prior sovereignty laws and Texas real property laws today.

\section{A. Current Texas Property Law}

Texas real property law is different from the property law in other states primarily because of the switching of sovereignties and the State's territorial Treaty with Mexico; under international law, private property should remain undisturbed by sovereignty changes. ${ }^{170}$ The previous laws that individuals abided by still govern unless they conflict with the new sovereign and until the new government changes them. ${ }^{171}$ However, the new government is not bound by an international treaty to continuously follow the property laws of the former sovereign because doing so would go against the standard that real property should be governed by the laws where the land is located. ${ }^{172}$ This being the case, the Treaty of Guadalupe Hidalgo is only in place to protect Spanish and Mexican titles against "discriminatory legisla-

166. Kerlin, 263 S.W.3d at 924-28.

167. Schwarz v. State, 703 S.W.2d 187, 189-91 (Tex. 1986).

168. See Walker, supra note 10, at 241-42; Bowden, supra note 6.

169. Walker, supra note 10, at 246.

170. Validity, supra note 5, at 439.

171. Hoffman, supra note 132, at 511.

172. Id.; see Amaya v. Stanolind Oil \& Gas Co., 158 F.2d 554, 558-59 (5th Cir. 1946). 
tion." 173 This means later enacted Texas state provisions would be invalid if they required the owners of Spanish and Mexican land grants to fulfill obligations not originally required of them under the previous sovereign. ${ }^{174}$ However, it also means the rights of Mexican and Spanish land grant holders will not trump the rights of landowners in Texas. ${ }^{175}$

Although a person may have a superior right to real property against third parties this does not mean they have a vested right; the legislature has the ability to change the law under which vestment was originally authorized. ${ }^{176}$ However, an owner of a land grant will be protected if the Court agrees that the land was a part of the territory when the grant was created. ${ }^{177}$ However, the rights and the laws regarding such ownership are not always clear.

\section{Mineral Estate Rights in Texas}

To fully understand the competing interests at stake, it is important to at least have some knowledge of what mineral estates in Texas are, who has an interest in the rights, and what those rights entail.

Although the Texas Constitution of 1866 released rights to mineral estates to surface owners, including owners of land grants, when the State of Texas conveys land today to a private owner, the State of Texas will retain the mineral estate. ${ }^{178}$ In 1945, the Supreme Court of Texas heard a dispute regarding a land grant conveyed to Jose Ballí. ${ }^{179}$ Because of the holding, the Texas legislature changed the Texas Constitution, restoring mineral rights to landowners and not the State. ${ }^{180}$ Although the Balli case was a dispute over sulphur, the resulting changes provide Texas landowners the right to convey or transfer land, mineral rights, or both. ${ }^{181}$ Under Texas law today, if a conveyance of land does not mention the minerals, it is assumed that the minerals are passed on to the purchaser of land. ${ }^{182}$ However, if an original land grant does not mention the minerals, the rights to the minerals remain with the seller and will pass on to the seller's heirs. ${ }^{183}$

Mineral estate ownership includes a right to "develop the minerals and the obligation to pay the costs of development."184 Mineral rights

173. Hoffman, supra note 136, at 511.

174. Id. at 511, 526-27.

175. Id. at $511-12$.

176. Id. at 517.

177. Id. at 524 .

178. Schwarz, 703 S.W.2d at 190.

179. HEIRS, supra note 5, at 3; State v. Balli, 190 S.W.2d 71 (Tex. 1944).

180. Id.

181. HEIRS, supra note 5, at 3.

182. Id. at 4.

183. Id.

184. Joseph Shade, Primer on the Texas Law of Oil and Gas 12 (Matthew Bender, 4th ed., 1996). 
to land purchased can be severed from the surface rights to the land and if they are not expressly granted, a seller will retain the mineral rights. ${ }^{185}$ The mineral estate may be conveyed as a fee simple or lesser estate. ${ }^{186}$ In addition, if there is a severed mineral estate granted in another, that estate is dominant so that the owner may enter upon the surface to an extent "reasonably necessary" to reach the minerals. ${ }^{187}$ Exceptions to this can be made in the mineral lease itself; for example, a mineral estate owner can waive any rights to access the surface. ${ }^{188}$ The owner of this dominant mineral estate does not have absolute ownership while the oil or gas remains underground and will not have such ownership until he is in actual possession of the minerals. ${ }^{189}$ While it is still in the earth, oil and gas are considered real property, but once a mineral estate owner has actual possession of that oil or gas, it becomes personal property. ${ }^{190}$

A surface owner is also "entitled to an accommodation of estates if the mineral lessee has a reasonable alternative that would serve the public policy of mineral development while also permitting use of the surface for productive agriculture." 191 Once a mineral estate has been conveyed, adverse possession of the surface estate will not adversely affect the mineral estate. ${ }^{192}$

When a mineral estate owner conveys or leases his estate to another, he has the option of retaining a royalty interest in the oil and gas. ${ }^{193}$ A royalty interest is "a certain proportion of the oil, or its value, or a certain sum per producing well in the case of gas, which is payable only in case oil or gas is produced" and which is non-posses-

185. Judon Fambrough, Minerals, Surface Rights, and Royalty Payments, Real Estate Center Texas A\&M University, Technical Report 840, Nov. 2009, at 1; Acker v. Guinn, 464 S.W.2d 348, 352 (1971) ("A grant or reservation of minerals by the fee owner effects a horizontal severance and the creation of two separate and distinct estates: an estate in the surface and an estate in the minerals.").

186. Humphreys-Mexia Co. v. Gammon, 254 S.W. 296, 299 (1923).

187. Acker, 464 S.W.2d at 352 ("This [mineral] estate is dominant, of course, and its owner is entitled to make reasonable use of the surface for the production of his minerals."); See also Fambrough, supra note 185; Shade, supra note 184, at 12.

188. Fambrough, supra note 185 , at 1.

189. Tex. Co. v. Daugherty, 176 S.W. 717, 719 (Tex. 1915); see also Shade, supra note 184 , at 12 .

190. See Susan Combs, Texas Comptroller of Public Accounts, Window on State Gov'Ts, http://www.window.state.tx.us/taxinfo/audit/unclaimed/04_Mineral_Interest_ to_Unidentified_Deposits.htm ("A mineral interest is fundamentally an interest in real property, while proceeds from the sale of oil and gas production are considered intangible personal property subject to unclaimed property statutes."); Christopher Jensen et al., Unclaimed Property in the Oil and Gas Industry: What Companies Need to Know about Mineral Proceeds Suspense Accounts, Ryan (Feb. 15, 2013), http:// www.ryan.com/Assets/Downloads/Articles/AUP-What-Companies-Need-To-KnowAbout-Mineral-Proceeds-Suspense-Accounts.pdf.

191. Fambrough, supra note 185 at 2.

192. Elliott v. Nelson, 251 S.W. 501, 504 (Tex. 1923); HEIRS, supra note 5, at 3.

193. Shade, supra note 184, at 14. 
sory and free from the cost of production. ${ }^{194}$ A royalty interest is an uncertain right because the value of such a right is speculative as it depends on possible future production. ${ }^{195}$ It is this royalty interest that Spanish and Mexican land grant heirs are seeking to recover from the lands once owned by their ancestors.

Today, oil and gas companies are the primary lessees of mineral estates in Texas. ${ }^{196}$ These entities must find owners of every portion of the mineral estates they are interested in and obtain valid leases from each of those owners. ${ }^{197}$ In the event an oil and gas company is unable to find an owner of a portion of a mineral estate, it will request a receivership from a court in which an attorney represents the unknown owner in negotiating the terms of the lease. ${ }^{198}$ When an oil and gas company has a receivership lease to a mineral estate, the company holds the oil and gas royalty for three years and then the royalties, as agreed in the lease, are reported to the Texas Comptroller of Public Accounts. ${ }^{199}$ If the Comptroller's office is unable to locate the mineral estate owners, the royalties are transferred to the state's general revenue fund earning interest that the state keeps. ${ }^{200}$ Heirs with valid land grants hope to receive a payout of royalties from this general revenue fund. ${ }^{201}$ In 2012, gas operators ended up giving $\$ 47.5$ million to the State and only $\$ 19.5$ million was given to owners who came forward to claim their royalties. ${ }^{202}$

Additionally, the normal four-year statute of limitations in sales tax transactions does not apply to unclaimed property. ${ }^{203}$ In addition, various property and civil practice codes from the 1980s set a retrospective cut-off date upon which the State could demand delivery of unclaimed property. ${ }^{204}$

194. Id.

195. $I d$.

196. See Hiller, supra note 13 , at 3.

197. Id.

198. Id.

199. Id.; see also, Texas Comptroller, supra note 190; Jensen, supra note 190, at 1; HEIRS, supra note 5, at 6.

200. Hiller, supra note 13; see also Jensen, supra note 190, at 3 ("many division orders have gone through three generations, and the related decimal interests are getting smaller, further complicating the associated division of interest."); HEIRS, supra note 5, at 6 (the State is required to hold funds (dating back to 1985) in escrow for mineral estate).

201. HEIRS, supra note 5, at 6 (these funds are available and may be claimed by heirs who take the initiative to declare them).

202. Hiller, supra note 13.

203. Texas Comptroller, supra note 190; see also Tex. Prop. Code Ann. § 74.308 (West 2013) (which eliminated the application of the four-year statute of limitations time bar on unclaimed property beginning September 1, 1987).

204. Texas Comptroller, supra note 190; see also Tex. Civ. Prac. \& Rem. Code AnN. \$16.004 (West 2013) (which established that September 1, 1987 is the earliest the state could require unclaimed property); Tex. Civ. Prac. \& Rem. Code Ann. $\S 16.070$ (West 2013) (which establishes that by contract, the earliest the state could recover unclaimed property would be September 1, 1985); Jensen, supra note 190, at 5 


\section{B. Heirs and Land Grant Claims Today}

In considering the rights of individual parties in title disputes, one writer noted, "we should not lose sight of what has been said to be among the most important elements to be considered in passing upon the validity of retroactive laws: reasonable expectations built on long faith in a bona fide purchase and on a long period of undisturbed possession." 205

Even though it has been over 250 years since the first Spanish land grant was issued, many families who remained on the land retain a portion of those original grants. ${ }^{206}$ Texas case law has favored State and private ownership of mineral estates by following the State's property laws, but on rare occasions, the State will utilize original Spanish and Mexican law if the outcome would support public interest. $^{207}$

Although an heir to a Spanish or Mexican land grant may claim title, if the ancestor abandoned the property, an heir will have a more difficult claim to prove, unless further evidence can support continued use of the land. ${ }^{208}$ Under original Spanish and Mexican law, a landowner lost title to land when "he ceased to occupy it with the intention of relinquishing his claim upon it."209

The current process for beginning a land grant claim in Texas includes gathering one hundred or more heirs of a particular land grant and providing documents demonstrating original ownership of the land. ${ }^{210}$ The group of descendants must then file a motion for declaratory judgment in order for a Court to establish the validity of their claim. ${ }^{211}$ Heirs may try to locate record titles to the mineral estates to determine the net worth of the land grant. ${ }^{212}$

\section{The Future for Heirs and Land Grant Claims}

\section{A. Heirs' Goals}

Support and research groups, such as Heirs Enforcing Inheritance Rights (HEIRS), promote legislative changes in favor of heirs receiving royalty payouts for mineral rights from unclaimed estates. ${ }^{213}$ HEIRS insists that it does not aim to encourage legislation that will

("There are generally no statutes of limitation in the unclaimed property arena, and a number of states reserve the right to "look-back" for extended periods on audit.").

205. Hoffman, supra note 136, at 528-29.

206. Scott, supra note 6, at ix-x.

207. Reich, supra note 76, at 85.

208. See 3 Aloysius A. Leopold, Texas Practice: Land Titles and Title Examination $\S 1.31$ ( 3 d ed.).

209. Id.

210. HEIRS, supra note 5, at 5.

211. Id.

212. Id

213. Id. at 1 . 
infringe on the rights of current landowners. ${ }^{214}$ Organizations such as the Land Grant Justice Association are dedicated to passing legislation that will benefit heirs of Spanish and Mexican land grants:

\begin{abstract}
A major part of achieving this goal is the understanding that the enactment of this historic law would not cause the expenditure of any tax monies, either in administration or claims payment, because the entire expense would be paid by monies currently held by the Comptroller and remitted by the Oil Companies as unclaimed royalties. ${ }^{215}$
\end{abstract}

\title{
B. Recent Legislation: House Bill 724 and its Potential Effects
}

HB 724 created a seventeen-member Commission to identify heirs of unclaimed mineral estates and to determine the value of those rights. ${ }^{216}$ The Commission is also charged with determining efficient procedures for the State to "notify the owners of proceeds . . . [and] ... distribute proceeds to the owners." 217 Commission members were appointed on December 31, 2013, and were required to schedule their first meeting no later than thirty days after all appointments were made. ${ }^{218}$ The commission's report is due by January 2015 and must include "proposed legislation necessary to implement the recommendations made in the final report." 219

Proponents of payouts to heirs of Spanish and Mexican land grants hope that HB 724 will bring heirs closer to realizing the recognition of original land ownership and substantial payouts from mineral estates on their lands. ${ }^{220}$

\section{Modern Social, Political, and Cultural Issues}

As Mexico modernizes, some commentators believe that communication and activity between Texas and Mexico will result in more Mexican law applied in Texas Courts. ${ }^{221}$

Texas attorney Eileen Fowler has a similar mission to encourage legislative change in favor of heirs' rights to mineral estates. ${ }^{222}$ However, others are pessimistic about the realization of payouts sought by heirs: "[T]here are formidable practical and political hurdles ahead. The descendents will have to prove their claims to the royalties, a point in dispute among experts. Beyond that, new legislation might be

214. Id.

215. Land Grant Justice Association, supra note 5.

216. HEIRS, supra note 5, at 7.

217. H.B. $724 \S 2(\mathrm{~b})(2)$.

218. H.B. $724 \S 2(\mathrm{e})-(\mathrm{f})$.

219. HEIRS, supra note 5, at 7; see also H.B. $724 \S 3(3)$.

220. See MacCormack, supra note 10; Spanish and Mexican Land Grants, supra note 5; Land Grant Justice Association, supra note 5, at 1.

221. Walker, supra note 10, at 230.

222. Spanish and Mexican Land Grants, supra note 5. 
necessary to resolve the issue."223 Although attorneys representing hundreds or even thousands of heirs are optimistic about large royalty payouts, "further obstacles loom. For starters, there's no pot of money waiting in Austin for anyone who can prove a claim. While hundreds of millions of dollars in unclaimed royalties have been paid to the State by energy companies, the funds have vanished into the State's general fund." 224 In addition, "if the state suddenly had to pay out huge claims, the Legislature would have to appropriate the money, a politically daunting assignment." 225 Attorneys and researchers who have worked closely with land grant disputes have concluded that the legislature will have to act in order for money to be paid to these probably well-deserving heirs. ${ }^{226}$

Allowing Mexican-American citizens to reclaim land rights once lost to their ancestors is difficult enough but more problems arise when Mexican immigrants raise the same claims to land rights. These native Mexicans refer to Mexico's and Texas' history, claiming United States citizens stole their ancestors' lands to support their argument that they should be able to enter the country legally. ${ }^{227}$ Many Mexican-Americans foster these claims under a movement called the "reconquista of the Southwest." 228 A more aggressive group, the Mexica Movement, attempts to "reconstruct" a portion of United States land (parts of California, Arizona, New Mexico, and Texas) back to its indigenous state and call it "Anahuac," or "Republica del Norte." 229

Some scholars assert that discrimination against heirs was present when original land claims were disputed and affected the outcomes of suits negatively against those of Mexican heritage, and still do today. ${ }^{230}$ This opinion stems from the idea that there should be "accountability and compensation for the theft of land" from the ancestors of these heirs now claiming these rights. ${ }^{231}$ These scholars argue that Mexican-Americans experience a "fragile existence" when it comes to the application of the law because they are citizens of color. ${ }^{232}$ These scholars assert that once Texas became a state, Mexi-

223. MacCormack, supra note 10, at 2, 3 .

224. $I d$. at 3 .

225. Id.

226. $I d$.

227. Mexican Aliens Seek to Retake "Stolen" Land, The Washington Times (Apr. 16, 2006), http://www.washingtontimes.com/news/2006/apr/16/20060416-122222-1672r/ ?page $=$ all.

228. Id.

229. Id.

230. Guadalupe T. Luna, On the Complexities of Race: The Treaty of Guadalupe Hidalgo Anddred Scott v. Sanford, 53 U. Miami L. Rev. 691, 714 (July 1999).

231. Haynes, supra note 9, at 232.

232. Luna, supra note 230, at 698. 
can-Americans experienced exclusion from achieving full citizenship due to stereotypes that leaked into the State's legal culture. ${ }^{233}$

Similar to Native-Americans, Mexican-Americans are "the only minority group in the United States . . . to be annexed by conquest and to have their rights allegedly safeguarded by treaty;" rights that should be recognized and upheld by the federal government. ${ }^{234}$ Failure of the federal government to take action that ensures adherence to the Treaty of Guadalupe Hidalgo "reveals a microcosm of race relations throughout the United States." ${ }^{335}$ These scholars assert that the United States' "desire to acquire and control land" through "dispossession of Mexican American landholders and the simultaneous enrichment of White America" results in this perceived inequity. ${ }^{236}$

The Treaty of Guadalupe Hidalgo provides that Mexicans living on Texas lands "shall be free to continue where they now reside;" but Texas Courts did not just distinguish occupied and vacant land, they required proof of validity of title from Spain or Mexico before recognizing Mexican land ownership. ${ }^{237}$ However, even these scholars acknowledge that the complicated and distant history of Spanish and Mexican land grants makes it very unlikely that heirs will ever be compensated for the losses their ancestors endured. ${ }^{238}$ The initial step may be public recognition of the injustices experienced by generations of land grant owners and heirs before compensation measures can even be considered. ${ }^{239}$ Applying standardized equal treatment guidelines for all parties involved in land grant disputes may help eliminate unfair and inconsistent Court rulings. ${ }^{240}$

In Fremont $v$. United States, an American citizen's claim to title was recognized despite the fact that similar claims (many of which were made by Mexican-Americans), where more convincing evidence was provided to prove ownership, were denied. ${ }^{241}$ The Treaty of Guadalupe Hidalgo gave Mexican citizens United States citizenship status which was constantly challenged and resulted in unequal treatment such as "[l]ynchings, segregation, denying Chicano soldiers returning from World War II the right to burial in their home-town cemeteries, poll taxes, and other measures."242

233. Id. at 701.

234. Haynes, supra note 9, at 235.

235. Id. at 235-36.

236. Id. at 236.

237. Treaty, supra note 6, at Art. VIII; Haynes, supra note 9, at 251.

238. Haynes, supra note 9, at 265.

239. Id.

240. See Frederico M. Cheever, A New Approach to Spanish and Mexican Land Grants and The Public Trust Doctrine: Defining the Property Interest Protected by the Treaty of Guadalupe-Hidalgo, 33 UCLA L. REv. 1364, 1395-1409 (June 1986).

241. See Luna, supra note 230, at 704-06.

242. Id. at 712 . 
Scholars who assert that Mexican-American landowners were purposefully excluded because of their race also believe that the same discriminations have carried into the present legal culture and that is why Mexican-Americans are still fighting for claims to their ancestors' lands. ${ }^{243}$ These exclusions resulted in an absence of Mexican-American presence in legal scholarship, academia, and the possibility of improving less-than fortunate communities, all of which mirrors the original conquest of the more advanced European colonization upon the culture of Mexicans. ${ }^{244}$

\section{CONCLUSION}

Spanish and Mexican land grants that were unrecognized by Texas are now being claimed by heirs who are hopeful that their rights will be validated. Decades of subsequent ownership on Texas land means that heirs are subject to Texas property law and may not be entitled to royalty interests in the mineral estates once owned by their ancestors. The recent passage of HB 724 will determine the rights of heirs, but this is a complicated task as commissioners must apply prior sovereignty laws as well as Texas property law. In addition, political issues such as the perceived history of race discrimination may influence the recommendations made by the commissioners.

Deciding what heirs are entitled to, after so many generations of unclaimed rights, will likely include a balancing of heirs' rights with the rights of current land and mineral estate owners, and the interests of the State of Texas. If the Commission or subsequent authorities determine that heirs do not have a legal claim, heirs may be entitled to an equitable remedy. This may not provide heirs with the payout they expect, but may nevertheless recognize and validate lost rights. However, recognition of heirs' rights will certainly not be realized at all if heirs and those who support them cease to assert their claims.

243. Id. at 714 .

244. Id. at 715 . 